Discussion Paper No. 08-019

\title{
Why Do Firms Train Apprentices? \\ The Net Cost Puzzle Reconsidered
}

Jens Mohrenweiser and Thomas Zwick

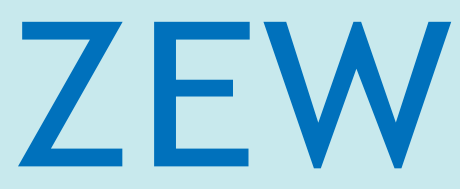

Zentrum für Europäische Wirtschaftsforschung $\mathrm{GmbH}$

Centre for European

Economic Research 
Discussion Paper No. 08-019

\title{
Why Do Firms Train Apprentices? The Net Cost Puzzle Reconsidered
}

\author{
Jens Mohrenweiser and Thomas Zwick
}

Download this ZEW Discussion Paper from our ftp server:

ftp://ftp.zew.de/pub/zew-docs/dp/dp08019.pdf

Die Discussion Papers dienen einer möglichst schnellen Verbreitung von neueren Forschungsarbeiten des ZEW. Die Beiträge liegen in alleiniger Verantwortung der Autoren und stellen nicht notwendigerweise die Meinung des ZEW dar.

Discussion Papers are intended to make results of ZEW research promptly available to other economists in order to encourage discussion and suggestions for revisions. The authors are solely responsible for the contents which do not necessarily represent the opinion of the ZEW. 


\section{Nichttechnische Zusammenfassung}

Praktisch alle Beiträge zur Ausbildungsmotivation deutscher Unternehmen gehen von dem stilisierten Fakt aus, dass die Unternehmen während der Ausbildungszeit Nettokosten zahlen müssen. Diese Behauptung stützt sich hauptsächlich auf nur eine Quelle - eine Serie von deskriptiven Querschnittstudien zu Kosten und Nutzen der dualen Ausbildung des Bundesinstituts für Berufsbildung (BIBB). Während viele einflussreiche theoretische Beiträge motivieren, weshalb die Unternehmen Nettokosten der Ausbildung akzeptieren, wurde der stilisierte Fakt selbst bisher nicht in Frage gestellt. Dieses Papier präsentiert deshalb eine die bisherige Literatur ergänzende Validierung der Nettokostenhypothese. Wir führen die erste kausale Untersuchung des Einflusses des Lehrlingsanteils auf den Betriebsgewinn durch. Wir nutzen hierfür multivariate Panelschätzmethoden, um unterschiedliche Quellen von Schätzverzerrungen und umgekehrter Kausalität berücksichtigen zu können. Unser Papier zeigt, dass zwischen unterschiedlichen Berufsgruppen unterschieden werden muss, wenn die Kosten und Nutzen der Ausbildung bewertet werden sollen. Insbesondere hat der Anteil von Lehrlingen in Handels-, Handwerks- und Bauberufen sowie kaufmännischen Berufen einen positiven Einfluss auf den Betriebsgewinn. Lehrlinge sind somit Substitute für Unoder Angelernte sind. Im Gegensatz dazu reduziert eine Erhöhung des Lehrlingsanteils in Fertigungsberufen den Unternehmensgewinn. Dies bedeutet, dass die Unternehmen, die Lehrstellen in diesen Berufen anbieten, ihre Ausbildungskosten während der Ausbildungsperiode nicht decken können. Die Lehrlingsausbildung ist für diese Betriebe somit eine Investition. Unser Beitrag zeigt gleichzeitig die Effizienz des deutschen Lehrlingssystems: es erlaubt den Unternehmen, in allgemeines und berufsspezifisches Humankapital in hoch spezialisierten Berufen wie Fertigungsberufen zu investieren. Zudem können Unternehmen in anderen Berufen, in denen Fähigkeiten allgemeiner und die Mobilität höher sind, kostenneutral ausbilden. 


\section{Nontechnical Summary}

Almost all papers on the motivation of German firms to train apprentices take as a stylised fact that training firms have to incur net costs. This notion stems practically from one source only - a series of descriptive cross section analyses of the costs and benefits of apprenticeship training conducted by the Federal Institute for Vocational Education and Training (BIBB). While an influential theoretical literature tries to motivate why firms should accept net training costs, the stylised fact itself has not been further tested. This paper therefore presents a complementary validation of the net cost hypothesis by simulating the decision personnel managers have to take when they want to replace unskilled or semiskilled employees by apprentices. It is the first causal assessment of the impact different occupational groups of apprentices have on gross enterprise profits. We use multivariate panel estimation techniques because we can hereby tackle several sources of estimation bias and reversed causality. Our paper shows that it is necessary to discriminate between different groups of occupations when assessing the costs and benefits of apprenticeship training. In particular, we find that the share of apprentices in trade, commercial, craft and construction occupations has a positive impact on contemporary gross profits and the apprentices are substitutes for unskilled or semi-skilled workers. In contrast, an increase in the share of apprentices in the manufacturing occupations reduces contemporary gross profits. This means that enterprises offering apprenticeships in manufacturing occupations do not cover their training costs during the apprenticeship period. The apprenticeship training rather is a human capital investment. This paper demonstrates the efficiency of the German apprenticeship system: it allows companies to provide general and occupation-specific skills in highly specified occupations such as manufacturing. Otherwise, it offers cost-neutral apprenticeships in occupations where skills are more general and the mobility is higher, such as commercial or trade occupations. 


\title{
WHY DO FIRMS TRAIN APPRENTICES? THE NET COST PUZZLE RECONSIDERED
}

\author{
Jens Mohrenweiser \\ University of Zurich \\ E-mail: jens.mohrenweiser@isu.uzh.ch \\ Thomas Zwick \\ Centre for European Economic Research (ZEW), Mannheim, Germany \\ E-mail: zwick@zew.de
}

March 2008

\begin{abstract}
This paper investigates the short-term costs and benefits of apprenticeship training in Germany. It calls into question the popular stylised fact that apprenticeship training always leads to net costs during the apprenticeship period. We analyse the impact of the proportion of different occupational groups of apprentices on firm performance. We use representative matched employer-employee panel data that allow us to correct for different sources of estimation bias. We show that the proportion of apprentices in trade, commercial, craft and construction occupations has a direct positive impact on firm performance: the companies cover their training costs immediately. In contrast, companies with apprentices in the manufacturing occupations face net training costs during the apprenticeship period but gain by the long-term employment of its graduate apprentices.
\end{abstract}

JEL Classification: C33, D24, J24

Keywords: apprenticeship training, performance, panel data estimation.

\footnotetext{
*This paper was supported by the Swiss Federal Office for Professional Education and Technology through its Leading House on Economics of Education, Firm Behaviour and Training Policies and by a grant of the German Research Foundation (DFG) "Heterogene Arbeit: Positive und normative Aspekte der Qualifikationsstruktur”. We thank Uschi Backes-Gellner, Kathrin Göggel, Simon Janssen, Matthias Kräkel, Christian Pfeifer, Juerg Schweri and Stefan Wolter for useful comments and the Research Data Centre (FDZ) of the Federal Employment Agency at the Institute for Employment Research (and here especially Peter Jacobebbinghaus) for the data access and the support with analysis of the LIAB data. The data basis of this publication is the Longitudinal Model (version 2) of the Linked Employer-Employee Data of the IAB, (years 1997-2002). Data access was via guest research spells at FDZ and afterwards via controlled data remote access at the FDZ.
} 


\section{Introduction}

The German dual apprenticeship system is often regarded as a potential model for other countries because it allows enterprises to provide and pay for training in specific and general human capital (Harhoff and Kane 1997; Acemoglu and Pischke 1999b; Steedman 2001). From an international perspective the apprenticeship system achieves high skill levels among young people who have not had a college-based education (Freeman and Schettkat 2001). It is also believed to lead to relatively low youth unemployment rates because it facilitates an orderly school-to-work transition (Ryan 2001).

In spite of these positive facts, the dual apprenticeship system seems to impose high costs on the training companies during the apprenticeship period and therefore forces these companies to invest in apprenticeship training. This is often seen as a competitive disadvantage for German companies facing increasing cost pressure in globalised markets. A frequently used argument is that enterprises are increasingly hesitant to accept net costs during the apprenticeship training period when they cannot be certain of retaining a sufficient number of apprenticeship graduates to earn these costs back after the apprenticeship period. This is a cause for concern because it is a widely assumed stylised fact that enterprises necessarily incur net costs during the apprenticeship period. This stylised fact stems from an influential series of descriptive cross-section costs and benefits evaluations by the Federal Institute for Vocational Education and Training (Bundesinstitut für Berufsbildung - BIBB), which shows that almost all training companies incur sizeable net costs.

Since apprenticeships are unanimously considered to offer general skills, the assumption of inevitable net costs during apprenticeship training seems to be a puzzle because it contradicts the fundamental results of the human capital theory by Becker (1964). It has accordingly motivated many theoretical studies to analyse market imperfections as a source of company-sponsored general training (Franz and Soskice 1995; Acemoglu and Pischke 1998; Acemoglu and Pischke 1999a; 
Kessler and Lülfelsmann 2006). Many seminal empirical studies of the German apprenticeship system also make the assumption of net costs without testing it (Harhoff and Kane 1997; Acemoglu and Pischke 1998; Dustmann and Schönberg 2004). While there seems to be an abundance of theoretical explanations for the stylised fact of net costs, the 'fact' itself has not been subjected to scrutiny, although it is one of the keys to understanding the dual apprenticeship system and to evaluating it by comparison to other training systems.

In this paper we therefore aim to shed more light on the question of whether German enterprises invest in human capital when they offer apprenticeships. We establish a causal assessment between the decision of an establishment to take on a certain number of apprentices and its performance. This approach contributes to the existing literature in two ways. First, we replicate the decision of personnel managers to take on an apprentice instead of an unskilled or semi-skilled employee including all other relevant factors. We estimate multivariate panel production functions in order to take into account selectivity and simultaneity of the share of apprentices as well as unobserved heterogeneity between establishments. That might bias descriptive cross-section accounts of costs and benefits. Second, we divide the group of apprentices into three main occupation categories - manufacturing occupations, craft and construction occupations, and trading and commercial occupations. The occupation is a better predictor for training costs and productive benefits than the type of training establishment, such as sector or firm size, which has normally been used up to now for the assessment of the hypothesis that enterprises incur net costs during apprenticeship training (Fougère and Schwerdt 2002). Thereby, we uses the fact that most occupations vary neither variations in specialisations nor training time. This means that apprentices of a certain occupation are very similar - large differences can be found however between the costs and benefits of manufacturing and craft occupations (Franz and Soskice 1995) and the skills demands in manufacturing and commercial occupations (Doeringer and Piore 1971). 
We show that (an increase in) the proportion of apprentices in trade, commercial, craft, and construction occupations has a positive impact on contemporary firm performance. The apprentices' relative productivity balances out their relative cost and they are potential substitutes to unskilled or semi-skilled workers. In contrast, apprentices in manufacturing occupations cause net training costs - contemporary firm performance decline when their share on the employees increases. This means that enterprises employing apprentices in metal-working or electronics, for example, have to invest in human capital during the training period and they profit from employing the apprenticeship graduates.

These results shed new light on discussions of the German apprenticeship system. The most important conclusion is that the system does not represent an anomaly, because enterprises do not accept net costs during apprenticeship training in which they provide general skills to apprentices who may potentially leave after the apprenticeship period. Apprentices in commercial and trade occupations, such as clerks, are sufficiently productive during their apprenticeship to cover the costs of their training themselves. These occupations require more general skills, ones that are applicable in different enterprises and industries. Further, apprentices in craft occupations, such as hairdressing or brick-laying, are also sufficiently productive to cover their training expenditure during the apprenticeship. On the one hand these apprentices quickly realise productivity gains and on the other hand they receive relatively low wages (Wolter et al. 2006). Finally, manufacturing apprentices require a larger share of specific skills that take time to acquire. In addition, they earn substantially higher wages on average than apprentices in craft occupations. They can apply their skills only in a specific industry and they are often part of strong internal labour markets. Therefore, firms can afford to exempt their manufacturing apprentices from paying for their training themselves during the training period. Furthermore, our results demonstrate the efficiency of the dual apprenticeship system: it incurs net costs only for those companies in manufacturing occupations. Here firms have to invest 
in order to obtain adequately trained employees because these are not easily available on the labour market. Interestingly, in these occupations, companies train apprentices also in mostly school-based systems for vocational education - here Britain is an example (Ryan et al. 2007).

The remainder of this paper is structured as follows: first we present an overview of the discussion of whether establishments incur net costs during apprenticeship training (section 2). Then we describe our theoretical framework of apprenticeship training (section 3) and our estimation approach (section 4). In the fifth section we discuss our data set and in the sixth section we present the results. The paper ends with a discussion of our results.

\section{Costs and Benefits of Apprenticeship Training}

There is a broad literature that singles out the dual apprenticeship system in Germany as an anomaly because the companies pay for the provision of general human capital and they do not recoup their costs until the end of the training period (Franz and Soskice 1995; Harhoff and Kane 1997; Acemoglu and Pischke 1998; Acemoglu and Pischke 1999b; Dustmann and Schönberg 2004; Lülfelsmann and Kessler 2006). This seems to be a puzzle because in theory, firms should be interested in paying only for specific non-transferable skills, while the apprentices should pay for general skills themselves.

Many contributions try to solve this perceived puzzle by explaining the willingness of firms to pay for general human capital through reference to different sources of market imperfections. Outside firms might find it difficult to judge the quality of the training programme in other firms (Katz and Ziderman 1990; Chang and Wang 1996) or there might be asymmetric information about the productivity of apprentices (Elbaum and Singh 1995; Franz and Soskice 1995; Acemoglu and Pischke 1998). These market imperfections would allow the firms to pay their own apprenticeship graduates less than the market wage for skilled workers and hereby recoup the net costs incurred during the apprenticeship period 
(Acemoglu and Pischke 1999a). Moreover, there might be complementarities between general and firm-specific skills. General skills can be used more efficiently when the worker has some firm-specific knowledge and skills and it is possible for the training firm to obtain some of the returns of general training (Franz and Soskice 1995; Acemoglu and Pischke 1999a; Kessler and Lülfesmann 2006). Furthermore, labour market institutions, such as minimum wages, unions or works councils, can induce enterprises to accept net costs during the apprenticeship period (Acemoglu and Pischke 1999a; Dustmann and Schönberg 2004). Finally, there might be other costs for apprenticeship graduates and employees when apprentices move to another employer after their apprenticeship period, such as mobility costs, search costs, training on the job, etc. (Harhoff and Kane 1997; Acemoglu and Pischke 1998).

These theoretical contributions are all based on the stylised fact of net costs during the apprenticeship period in Germany. The net costs assumption stems from a series of cost benefit studies conducted by the BIBB (Bardeleben et al. 1997; Beicht et al. 2004). These evaluations calculated the relevant costs during apprenticeship training for about 50 occupations and compared them with the economic value of the productivity contribution of a typical apprentice. The evaluations are based on surveys of about 2,500 (personnel) managers who assessed one occupation each. They consistently find that all occupations and 96 per cent of the companies face sizeable net costs during the apprenticeship period. ${ }^{1}$ Drawbacks of the descriptive cross-section results may be the bias incurred by the endogeneity of apprenticeship training and unobserved differences between firms. Causality is also hard to infer here.

The results of the descriptive costs and benefits calculations are, however, thrown into doubt by some recent empirical studies. First, Mohrenweiser and Backes-Gellner (2008) show that about 14 per cent of German training enterprises consistently do not take on their apprenticeship graduates during a period of

\footnotetext{
${ }^{1}$ This refers to the full cost account, which is usually cited in scientific publications.
} 
several years. This contradicts the notion of there being net costs during the apprenticeship period for virtually all training enterprises, because these companies have no opportunity to recoup the net costs. Second, in a costs and benefits study for Switzerland also based on surveys of personnel managers, Wolter et al. (2006) find that two-thirds of Swiss companies with fewer than 100 employees and one-half of the larger ones are able to recoup their training costs during apprenticeship training. The differences between the two countries are quite surprising, because the training systems in both countries are very similar. Third, Zwick (2007) finds on the basis of multivariate panel profit estimation that an increase in the ratio of apprentices does not decrease profits. He concludes that, on average, German establishments do not face net costs during the apprenticeship period.

Those studies which do not find net costs from training enterprises name the substitution or production motivation of the companies as an alternative to investment motivation (Lindley 1975). The substitution strategy states that the productivity of the apprentices is higher than their training costs and the unit labour costs of apprentices are lower than the unit labour costs of other substitutable employees (in general, unskilled or semi-skilled workers).

Besides the study by Zwick (2007) there are only two studies we are aware of that assess the causal effect of apprenticeship training on firm performance. Fougère and Schwerdt (2002) analyse the contribution of apprentices on firm performance in Germany. They find a positive effect of apprentices on the value added only in medium-size firms. Askilden and Nilsen (2005) partly confirm the hypothesis that firms face net costs during apprenticeship training by analysing the recruitment of apprentices during the business cycle in Norway. They find that apprentices are substitutes for skilled workers and are recruited primarily in boom phases. However, all of these studies treat the apprentices as a homogeneous group and do not discriminate between the training occupations. 


\section{Theoretical Framework}

The German apprenticeship system is characterised by a duality of training sites, which means that the apprentices spend 1-2 days a week in a vocational school where they learn general and occupation-specific skills, and 3-4 days in the training company, where they mostly work and learn occupation-specific and firmspecific skills (see Franz and Soskice 1995 for a concise description of the system). The integration of the apprentices in the production process is an important part of the German apprenticeship system, because the companies can recoup the training costs in part or in full. Lindley (1975) therefore describes apprentices as cheap productive workers, who can substitute for unskilled or semiskilled employees because of their relatively low wages. This substitution training strategy can therefore be analysed by a simple micro-economic production model with two substitutable input factors (here: apprentices and unskilled or semiskilled workers) where the employment shares are dependent on their relative unit labour costs (Mohrenweiser and Backes-Gellner 2008).

In using the substitution training model we exploit the property of part-time productive work of the apprentices in their training companies and analyse a standard Cobb Douglas function, including the number of employees, weighted by their occupation or skill level (Dearden et al. 2006). Therefore, we aim at establishing a causal relationship between the decision of a company to recruit apprentices instead of unskilled or semi-skilled workers, and its performance.

Accordingly, our model divides the number of employees $(L)$ in different skill and occupational groups $(s)$, where $\theta$ refers to their performance differences:

$$
L=\sum_{s}\left(1+\theta_{s}\right) L_{s} .
$$

Then we define a reference category (in our case the proportion of unskilled or semi-skilled employees) and multiply all summands by $L / L$, logarithmise, use the approximation $s \approx \ln (s+1)$ for small $s$, define $l_{s}=L_{s} / L$, and solve to: 


$$
\ln L=\ln L+\sum_{s} \theta_{s} l_{s}
$$

Then we insert (2) in a standard logarithmic Cobb Douglas function and solve this to get:

$$
\ln \pi_{i t}=A+\alpha \ln k_{i t}+\beta \sum_{s} \theta_{s} l_{s i t},
$$

where $\pi$ is the establishment performance per capita, $k$ is the capital per head and the $l_{s}$ indicate the proportions of different skill or occupational groups $s$ in the company $i$ at time $t$ and $A$ are other company or market characteristics. The parameters $\alpha$ and $\beta$ are the elasticities of the Cobb Douglas function for capital and labour respectively and $\theta$ presents the profit differences between the skill and occupational groups.

In our approach, we do not consider the apprentices as a homogeneous group but divide them into three occupational categories: manufacturing occupations, craft and construction occupations, and trade and commercial occupations. ${ }^{2}$ We chose this classification because the cost/benefit relations differ between occupations (Wolter et al. 2006). Our occupational classification is not the same as that used by Beicht et al. (2004) who mainly differentiate occupations by the institutions involved (for example chambers of commerce and industry $v s$. chambers of crafts). In contrast, our occupational groups are chosen so that their impact on firm performance is as homogeneous as possible. Our classification takes into account the differences between blue-collar (manufacturing, crafts and construction) and white-collar (commercial and trade) apprentices on the one hand, and between manufacturing and craft occupations on the other.

The distinction between commercial and manufacturing apprentices can be motivated by the internal labour market literature and the skill weights approach. The internal labour market literature makes a strong distinction between bluecollar and white-collar workers in terms of the workers' tenure and their general

\footnotetext{
${ }^{2}$ The list of occupations in the three groups can be found in Table A8 in the Appendix.
} 
vs. specific human capital requirements and investments (Doeringer and Piore 1971). In detail, manufacturing apprentices face a stronger internal labour market and therefore a higher probability of company-sponsored training as well as a lower mobility after graduation because the apprenticeship is a port of entry into the internal labour market (Soskice 1994). A similar relation between training costs and the productive benefits of apprentices can be motivated by the skill weights approach (Lazear 2004). Here, bundles of skills are analysed and it is assumed that more general weighted skills bundles lead to higher job mobility. In our terms, commercial apprentices, such as clerks for example, acquire a more general weighted combination of skills such as languages, IT or social skills, and the apprenticeship graduates are more likely to find a better job offer elsewhere. Therefore, firms with apprentices in commercial occupations are forced to pursue a cost-neutral training strategy because they cannot be certain to recoup their training costs after the training period. We therefore propose our first hypothesis:

HYPOTHESIS 1: Apprenticeships in commercial and trade occupations do not involve net costs during the apprenticeship period, because the productive benefits cover the training expenditures.

Second, the differences between manufacturing $v s$. craft and construction occupations can be explained by the greater possibility of productive work time during the apprenticeship of craft and construction apprentices (Wolter et al. 2006). Prime examples are almost all construction occupations, where the apprentices are productive from the first training days on. For most craft employees, switching from one employer to another is quite widespread and easy because most skills are not company-specific. This is in contrast to the manufacturing occupations where the apprentices have to learn how to handle more complex machines and they cannot become productive very quickly. The required skills in these occupations, such as electronics or metal mechanics, are 
training- and cost-intensive and frequently company-specific (Wolter et al. 2006). Further, the crafts and construction apprentices are given clearly lower training wages, which makes it easier to recoup the training expenditure. This leads us to our second and third hypotheses:

HYPOTHESIS 2: Apprenticeships in manufacturing occupations involve net costs during the apprenticeship period.

HYPOTHESIS 3: Apprenticeships in craft and construction occupations do not involve net costs during the apprenticeship period.

\section{Empirical Framework}

In order to estimate the net costs of an apprenticeship required by an occupational group, we use a Cobb Douglas gross profit function according to equation (3):

$$
\ln \pi_{i t}=\delta_{1} \operatorname{com}_{i t}+\delta_{2} \text { man }_{i t}+\delta_{3} \text { crafts }_{i t}+x_{i t}^{\prime} \beta_{i}+\eta_{i}+u_{i, t},
$$

where $t$ is a time indicator, $i$ is an establishment indicator, com, man and crafts are the proportion of apprentices in commercial or trade, manufacturing, crafts or constructions occupations respectively. The dependent variable $\pi$ measures the firm performance per capita and $x$ is a column vector of other covariates including all variables in (3) such as capital per head and the proportion of skilled and unskilled workers as well as other explanatory variables. Finally, $\eta$ denotes the unobservable time invariant factors and $u$ stands for the normally distributed error term with an expected value of zero.

Our main focus lies on the impact of (an increase in) the share of apprentices from a certain occupational group on (the change in) contemporary gross profits. We assert that a negative impact of the contemporary share of an occupational group of apprentices on profits indicates net costs. An insignificant or even a positive correlation between the share of apprentices and gross profits 
indicates no net costs; or, in other words, the apprentices bear their training costs themselves by participating in productivity. Our estimation procedure takes into account different sources of estimation bias or endogeneity problems such as selectivity, unobserved heterogeneity and simultaneity. In order to assess the changes incurred by estimation biases, and as a benchmark, we start with a pooled estimation, i.e. a cross-section including observations from different years. This increases the number of observations; it also means that a firm that appears in several years is seen as a separate observation unit each time.

We control for time invariant unobserved variables influencing both firm performance and share of apprentices (unobserved establishment heterogeneity: $E(x, \eta) \neq 0)$. Examples for unobserved heterogeneity are the quality of industrial relations or the innovation pressure facing a firm. For example, our estimation may be upward-biased when good industrial relations lead to better firm performance on the one hand and to higher training endeavours on the other hand. It is also conceivable that higher profits are a consequence of good personnel management and this can also go along with relatively high efforts put into apprenticeship training. Time invariant unobserved heterogeneity is avoided by estimating the model in first differences or by demeaning the cross-section equations. In other words, in our second specification we explain the change in firm performance from one year to the next by means of a change in the composition of employee qualifications and other covariates.

A further possible source of estimation bias is the endogeneity of the share of apprentices. First, establishments may alter their qualification structure simultaneously with profits or both may be influenced by exogeneous shocks such as a positive trend in demand because they lead to an increase in the workforce. Otherwise, simultaneity can for example occur if relatively low profits are a signal for a structural labour costs problem which firms might try to solve by substituting apprentices for unskilled and skilled workers. Another source of estimation bias is selectivity in apprentice training. Neubäumer and Bellmann (1999) find for 
example that the probability to train is higher in industries with low net apprenticeship costs. These two sources of estimation bias are removed in our third estimation specification by an instrumental variable panel regression. It is convenient, in this respect, to use general method of moments (GMM) estimations with internal instruments, because lagged internal instruments do not pose causality problems contemporary external instruments might have given the assumptions stated below. In addition, we do not have enough external instruments for the potentially endogeneous variables. More precisely, the difference GMM Estimator instruments the first differences of the explanatory variables with the corresponding levels of the lagged variables whereby potentially endogenous variables need the lags $t$-2 and predetermined ones the lags $t-1$ (Arellano and Bond 1991). Therefore we make the so-called sequential exogeneity assumption $\left(E\left(x_{i, t}, \Delta u_{i, t-1}\right)=0=E\left(x_{i, t}, u_{i, t-1}-u_{i, t-2}\right)\right)$ which means that contemporary exogenous shocks have no impact on lagged explanatory variables. We therefore need at least four time periods, where the fourth lag is the instrument. Unfortunately, the predictive power of the internal instruments may be small if the time series are highly persistent. That means in our case for example that the qualification structure of the employees hardly changes from one year to another. That could evoke biases in the GMM Estimator in first differences (Arellano and Bover 1995).

Therefore we prefer the so-called System GMM Estimator by Blundell and Bond (1998). Here, the differences are instrumented again with lagged levels as internal instruments and the levels of the covariates are simultaneously instrumented by adequate lagged differences. The main advantage of this approach is that besides the temporary differences, differences in levels between firms are also taken into account. This improves the information used in identifying the effect and usually enhances the precision of the estimator. A necessary condition for the System GMM Estimator is that the correlations between the unobserved fixed effects and the first differences of the covariates remain constant over time 
(Arellano and Bover 1995). ${ }^{3}$ In our investigation this means for example that the particular propensity for personnel management or industrial relations does not change much over the analysed time period of six years. The estimations are carried out with the help of a two-step method under the application of Windmeijer's adjustment process for variances (Windmeijer 2005), using the command xtabond2 in STATA 9.2 (Roodman 2006). In addition, we impose common factor restrictions using a minimum distance estimator in order to obtain a single coefficient for all covariates in the dynamic model (Blundell and Bond 1998).

We can identify the effect of changes in the proportion of occupational groups of apprentices on firm performance because of market inflexibilities, i.e. in this case by dismissal protection. While the firms can directly affect their share of apprentices, shrinking firms may face an inefficient composition of staff because employees cannot be replaced and laid off at will (Berthold and Fehn 1998). Another reason for inflexibilities and an inefficient composition of the workforce may be a lack of suitably skilled job applicants (Kölling 2002). As a consequence, some firms might not have their optimal employee mix and an increase in the share of a particular employee group would influence gross profits.

\section{Data}

Our data are taken from the waves 1997-2002 of the linked employer employee data set of the IAB (LIAB). The LIAB combines Federal Employment Agency individual-based employment statistics with plant-level data from the IAB Establishment Panel. The distinctive feature of the LIAB is the combination of administrative information on individuals and details concerning the establishments that employ them.

The employment statistics of the LIAB are drawn from the German employment register, which contains information on more than 98 per cent of the

\footnotetext{
${ }^{3}$ This is also called the stationarity assumption, given the derived stationarity from this assumption.
} 
employees and trainees included in the establishment panel (Alda 2005). The information on the schooling level of the employees may be inconsistent because the information is not obligatory. Therefore we use the correction method proposed by Fitzenberger et al. (2006).

To take account of the top coding of earnings at the earnings ceiling for social security contributions for roughly 11 per cent of the sample, we impute wages for those employees at the censored level. To this end, we first create 20 cells differentiated by gender, education (the six schooling groups identified in Appendix Table A1) and nationality (German $v s$ non-German), and run censored wage regressions for each cell. The covariates comprise age, age squared, and dummies for job characteristics. Further, our procedure takes into account that the level at which wages are top coded differs between eastern and western Germany and is adjusted every year. Predicted wages for each censored observation are then calculated and imputed for each individual.

The plant-level component of the LIAB, the IAB Establishment Panel, was initiated in 1993 (Kölling 2000). It is based on a stratified random sample - strata for 16 industries and 10 employment size classes - from the population of all establishments. Although larger plants are over-sampled, within each cell the sampling is random.

All labour-related variables are calculated from the reliable individual Social Security Records and all other company-related variables are compiled from the IAB Establishment Panel. We use the so-called longitudinal version of the LIAB which includes daily information on the employee characteristics for all establishments. We calculate on a monthly basis the proportion of all employmentrelated variables and then derive their yearly mean. This approach is mainly chosen because the proportion of apprentices changes cyclically during the year, with a minimum around July and a maximum around the new year, and the training period differs between occupations: for example most apprenticeship training in commercial occupations takes three years while apprenticeships in 
manufacturing usually last three and a half years. Therefore, the cross-section data that entail the employee characteristics on only one day per year - the $30^{\text {th }}$ of June - underestimate the true ratio of apprentices. Even more importantly, the difference between the true average proportion of apprentices and the measured proportion of apprentices at this date differs between the groups of apprentices because of the different training durations (Jacobebbinghaus et al. 2008).

In obtaining our estimation sample, we exclude not-for-profit organisations and agriculture and mining establishments, as well as establishments that do not report sales (such as banks and insurance companies). We also exclude establishments with fewer than 20 employees ${ }^{4}$ and any establishments that have more than 60 per cent apprentices in their workforce (training companies). In addition, only individuals aged between 19 and 64 years and covered by social security are included in the sample. We also omit all employees with wages lower than the minimum income limit for compulsory social insurance, and apprentices who earned more than the social security contribution ceiling. Matching the selected employees to the selected establishments results in a sample of 1879 establishments.

The firm performance variable is the gross profit per head calculated by subtracting the total wage bill and the inputs from firms' revenue. We take logs in order to reduce the impact of outliers. As we do not have a variable directly indicating capital and capital costs in the panel, we can only include investments as a control variable proxy using the perpetual inventory method (Zwick 2004). We assume that using aggregated investments instead of capital is innocuous, especially in the estimation specifications based on differences, because it seems improbable that capital costs vary with the proportion of apprentices employed. However, in contrast to other variables it is not clear whether high investments boost gross profits or whether high gross profits enhance the investment affinity.

\footnotetext{
${ }^{4}$ This excludes the group of firms for which the calculated net costs are near to zero (Bardeleben et al., 1997, Beicht et al. 2004). Therefore we might actually have downwards biased results.
} 
Investments, gross profits and employee characteristics are divided by the number of employees in order to avoid having to measure scale effects such as a positive correlation between the levels of investments and profits.

\section{Findings}

Our three homogeneous occupational groups cover 85 per cent of all apprentices. More specifically, commercial and trade occupations cover 25 per cent, crafts and construction occupations 30 per cent and manufacturing occupations 30 per cent of all apprentices. The entire summary statistics on establishment (mean) characteristics for the estimation sample used for the System GMM regressions are given in Table A1 of the Appendix.

Our pooled OLS estimation in Table 1 suggests that the contribution of apprentices to the gross profits in commercial or trade occupations is significantly positive in comparison to that of unskilled or semi-skilled workers. In contrast, the contribution of crafts and construction apprentices, as well as that of manufacturing apprentices, is significantly negative correlated with the gross profit. All further covariates have the expected signs (see Table A2 in the Appendix): higher investments per capita, the presence of works councils, collective bargaining, and the export share are positively correlated with gross profits. The share of employees with a lower than tertiary-level qualification has a negative correlation, while the share of employees with a higher qualification is positively correlated with gross profits.

The pooled regression is possibly biased, however, because observations of the same firm in different years are considered as independent, and unobserved heterogeneity cannot be taken into account. The Fixed Effects Gross Profit Regression (FEM) in Tables 1 and A3 has, correspondingly, a smaller number of significant coefficients. The contribution of all apprentice groups to firm performance is now insignificant. 
In order to tackle endogeneity, we prefer a System GMM approach with lagged levels respectively lagged differences as internal instruments. More specifically, we treat worker-related variables as potentially endogenous (apprentices' occupation and job characteristics - see Appendix) and instrument them with lags (t-2) and all further available lags. The investment variable is seen as predetermined and is instrumented with lag ( $\mathrm{t}-1)$ and further lags. All establishment-related variables (works councils, industry and so on, see Appendix) are seen as exogenous. The System GMM Estimation is reported in Table A4 in the Appendix. All test statistics confirm our specification (autocorrelation tests and test of over-identification restrictions) and the coefficients of the lagged dependent variable are in the expected range between the lagged OLS and the lagged FEM specification (Roodman 2006) - see Tables A6 and A7.

Table 1: Gross Profit Estimation, Dependent Variable: log(value added minus total wage bill per capita)

\begin{tabular}{|c|c|c|c|c|c|c|}
\hline & \multicolumn{2}{|c|}{ OLS } & \multicolumn{2}{|c|}{ FEM } & \multicolumn{2}{|c|}{ Sys GMM } \\
\hline & Coeficent & t-Value & Coeficient & t-Value & Coeficient & t-Value \\
\hline \multicolumn{7}{|l|}{ Share of Apprentices in: } \\
\hline Commercial or Trade Occ. & 1.8628 & 7.61 & -0.3443 & -0.91 & 0.9683 & 2.78 \\
\hline Manufacturing Occ. & -0.6416 & -3.25 & -0.2180 & -0.65 & -1.2437 & -2.65 \\
\hline Crafts or Constructions Occ. & -0.6695 & -3.62 & 0.2423 & 0.68 & 1.4731 & 3.80 \\
\hline Number of Establishments & \multicolumn{2}{|c|}{8169} & \multicolumn{2}{|c|}{2146} & \multicolumn{2}{|c|}{1879} \\
\hline $\mathrm{R}^{2} /$ Number of instruments & \multicolumn{2}{|c|}{0.1773} & \multicolumn{2}{|c|}{0.0195} & \multicolumn{2}{|c|}{269} \\
\hline
\end{tabular}

Comments: all coefficients significant at the 1\% level, full output in the Appendix Tables A2-A5, reference category: unskilled workers. Source: LIAB waves 1997-2002.

Taking endogeneity into account shows, according to our Hypothesis 1, that apprentices in commercial and trade occupations have a positive impact on gross profits in comparison to unskilled and semi-skilled workers. In detail, a one per cent increase in the proportion of commercial apprentices raises the contemporary gross profit by around one per cent. The apprentices in commercial and trade 
occupations are obviously on average sufficiently productive to cover the training expenditures during the training period. Therefore, these apprentices are potential substitutes for unskilled or semi-skilled workers. In accordance with our second hypothesis the contribution of manufacturing apprentices to the firm's gross profits is negative in comparison to unskilled workers. These apprenticeships therefore impose net costs on the companies during the training period, and their benefits have to come in the form of the employment of skilled own apprenticeship graduates. Further, apprentices in craft and construction occupations have a significantly more beneficial impact on gross profits than unskilled workers, which confirms our third hypothesis. These apprentices cover their training costs through their productive working time during the apprenticeship. In contrast to the manufacturing occupations, these occupations do not need to take over the apprenticeship graduates in order to cover their net training costs. Finally, the lagged endogeneous variable and the proportion of skilled employees have a positive significant impact on profits while the proportion of part-time employees and the size of investments per capita have no impact. Exporting firms and firms with works councils have a higher gross profit (see Table A4 and A5 ).

In Germany in recent years, more school leavers have applied for apprenticeships than enterprises have offered apprenticeship openings. In the public debate, frequently the argument is made that apprentices are too expensive and a reduction in apprentice salaries might increase the inclination of enterprises to offer apprenticeships (Zwick 2007). It therefore seems interesting if the influence of apprentices on productivity is different from their impact on gross profits (i.e. productivity minus the wage sum). The respective results are reported in Tables A2-A7. Comparing both parts of the tables suggests that usually the impact on productivity is more positive (or less negative) than the impact on gross profit. This means that the commercial apprentices are more productive than unskilled workers (given their productive working time) but their relatively higher 
training wages reduce the benefits. Nevertheless, the apprentices still have more favourable unit labour costs than unskilled or semi-skilled workers. Another possible interpretation is that the costs of an increase in the proportion of apprentices are higher than those for an increase in the proportion of unskilled or semi-skilled employees, where one has to take into account the indirect salary costs for supervisors. An exception is the relation between profits and productivity for the craft and construction occupations in the MDE specification (see Table A5). Here the gross profit impact is about the same as the productivity impact. This might be a consequence of relatively low apprentice wages and other training costs in enterprises that train apprentices in craft or construction occupations (or relatively high productivity of apprentices in relation to their relative costs).

In order to check the robustness of our results, we also calculate everything in deviations from sector means. This slightly changes the interpretation because we cancel out the level effects between sectors. Now the question is whether a higher share of apprentices in certain occupations than the sector average goes hand in hand with a higher gross profit than the sector average. The results are very similar to those presented before and therefore we do not display them separately here. In addition, we also run all regressions for the average apprenticeship share instead of differentiating between occupations groups. We obtain a result analogous to that of Zwick (2007): on average the share of apprentices is uncorrelated with gross profits (and productivity).

Summing up, we find that firms pursue a cost-neutral training strategy in commercial and trading as well as construction and craft occupations. In contrast, the apprentices in manufacturing occupations are more costly than their unskilled or semi-skilled potential substitutes and therefore these apprenticeships are an investment in human capital for the training companies. 


\section{Conclusions}

This paper presents the first causal assessments of the impact of different occupational groups of apprentices on gross enterprise profits. It shows that it is necessary to discriminate between different groups of occupations when assessing the costs and benefits of apprenticeship training. In particular, we find that the share of apprentices in trade, commercial, craft and construction occupations has a positive impact on contemporary gross profits and the apprentices are potential substitutes for unskilled or semi-skilled workers. In contrast, an increase in the share of apprentices in the manufacturing occupations (which constitute about $30 \%$ of all apprentices) reduces contemporary gross profits. This means that enterprises offering apprenticeships in manufacturing occupations do not cover their training costs during the apprenticeship period. The apprenticeship training rather is a human capital investment by these companies. There are usually two reasons proposed for the motivation of net costs during apprenticeship training. The first is the possibility to recoup training investments by taking apprentices over as skilled workers and paying them a lower than the market wage (Acemoglu and Pischke 1998). The second reason is that not sufficient adequately skilled workers are available on the labour market (Fougère and Schwerdt 2002).

Our findings challenge the stylised fact based on descriptive cross-section analyses, that almost all training enterprises necessarily incur net costs during apprenticeship training. However, our findings are in line with the fact that a significant proportion of enterprises in Germany never recruit their apprenticeship graduates (Mohrenweiser and Backes-Gellner 2008), because they obviously do not need to recoup net costs after the apprenticeship period. It also supports the finding that the average proportion of apprentices does not have a significant impact on gross profits (Zwick 2007). Our results are, finally, also comparable with what is found in Switzerland. In both countries a large number of young people (especially in commercial, trade, craft and construction occupations) are trained at no net cost during their apprenticeship training (Wolter et al. 2006). 
Adolescents in these occupations are mostly trained in schools or universities also in school-based vocational education systems like those in the UK. In contrast, in the manufacturing occupations, British companies too offer apprenticeships, which are also human capital investments for the companies (Ryan 2007).

It seems promising to validate our results by directly testing the investment hypothesis for different occupations on the wage differences between apprentices who stay at their training firms and those who switch employers after the apprenticeship. According to our results wages of manufacturing apprentices should be lower if they stay while there should be no differences in wages for the two other groups of occupations. Moreover, future empirical studies of the German apprenticeship system should incorporate the occupational differences, especially if they test theoretical models assuming net training costs.

This paper demonstrates the efficiency of the German apprenticeship system; it allows companies to provide general and occupation-specific skills in highly specified occupations such as manufacturing. Otherwise, it offers costneutral apprenticeships in occupations where skills are more general and the mobility is higher, such as commercial or trade occupations. In these occupations, companies do not need low workforce mobility and regulated labour markets to make training worth their while. 


\section{References}

Acemoglu, D. and J.-S. Pischke (1998), Why do Firms Train? Theory and Evidence, Quarterly Journal of Economics 113: 79-119.

Acemoglu, D. and J.-S. Pischke (1999a), The structure of wages and investment in general training, Journal of Political Economy 107: 539-72.

Acemoglu, D. and J.-S. Pischke (1999b), Beyond Becker: Training in Imperfect Labour Markets, Economic Journal 109: F112-F142.

Alda, H. (2005), Datenbeschreibung der Version 1.1 des LIAB Querschnittmodells, FDZ Datenreport 2/2005, Nürnberg.

Arellano, M. and S. Bond (1991), Some Specification Tests for Panel Data: Monte Carlo Evidence and an Application to Employment Equations, Review of Economic Studies 58: 277-298.

Arellano, M. and O. Bover (1995), Another Look at the Instrumental Variable Estimation of Error-Components Models, Journal of Econometrics 68: 29-51.

Askilden, J. and O. Nilsen (2005), Apprentices and Young Workers: A Study of the Norwegian Youth Labour Market, Scottish Journal of Political Economy 52: 1-17.

Bardeleben, R.v., U. Beicht, and K. Fehér (1997), Was kostet die betriebliche Ausbildung? Bundesinstitut für Berufsbildung (ed.): Berichte zur beruflichen Bildung, Heft 210, Bertelsmann, Bielefeld.

Becker, G. (1964), Human Capital, The University of Chicago Press: Chicago.

Beicht, U., G. Walden, and H. Herget (2004), Kosten und Nutzen der betrieblichen Berufsausbildung in Deutschland, Bertelsmann: Bielefeld.

Berthold, N. and R. Fehn (1998), Die zehn Gebote der Arbeitsmarktpolitik, Wirtschaftswissenschaftliche Beiträge des Lehrstuhls für Volkswirtschaftslehre, Wirtschaftsordnung und Sozialpolitik, Bayerische Julius-Maximilians-Universität Würzburg, Nr. 21.

Blundell, R. and S. Bond (1998), Initial Conditions and Moment Restrictions in Dynamic Panel Data Models, Journal of Econometrics 87: 115-143. 
Chang, C., and Y. Wang (1996), Human Capital Investment under Asymmetric Information: The Pigovian Conjecture Revisited, Journal of Labor Economics 16: 505-519.

Dearden, L., H. Reed and J. Van Reenen (2006), The Impact of Training on Productivity and Wages: Evidence from British Panel Data, Oxford Bulletin of Economic and Social Research 68: 397-421.

Doeringer, P. und M. Piore (1971), Internal Labor Markets and Manpower Analysis, Lexington, MA: D. C. Heath.

Dustmann, C. and U. Schönberg (2004), Training and Union Wages, IZA Discussion Paper 1435, Bonn.

Elbaum, B. and N. Singh (1995), The economic rationale of apprenticeship training: some lessons from British and U.S. experience, Industrial Relations 34: 593-622.

Fitzenberger, B., A. Osikominu and R. Völter (2006), Imputation Rules to Improve the Education Variable in the IAB Employment Subsample, Schmollers Jahrbuch 126 (3): 405-436.

Franz, W. and D. Soskice (1995), “The German Apprenticeship System”, in F. Buttler, W. Franz, R. Schettkat and D. Soskice (eds.): Institutional Frameworks and Labor Market Performance, Routledge, London: 208-34.

Freeman, R. and R. Schettkat (2001), Skill Compression, Wage Differentials and Employment: Germany vs. the US, Oxford Economic Papers 53, 582-603.

Fougère, D. and W. Schwerdt (2002), Are Apprentices Productive? Konjunkturpolitik 48: 317-346.

Harhoff, D. and T. Kane (1997), Is the German apprenticeship system a panacea of the U.S. labor market?, Journal of Population Economics 10: 171-96.

Jacobebbinghaus, P., J. Mohrenweiser and T. Zwick (2008), Wie kann die Ausbildungsquote in Deutschland korrekt gemessen werden?, ZEW mimeo.

Katz, E. and A. Ziderman (1990), Investment in General Training: The Role of Information and Labour Mobility, Economic Journal 100: 1147-1158. 
Kessler, A. S., and C. Lülfesmann (2006). The Theory of Human Capital Revisited: on the Interaction of General and Specific Investments. Economic Journal, 116: 903-923.

Kölling, A. (2000), The IAB Establishment Panel, Schmollers Jahrbuch 120: 291300.

Kölling, A. (2002), Fachkräftebedarf als betriebliches Matching-Problem, Mitteilungen aus der Arbeitsmarkt- und Berufsforschung 35: 566-579.

Lazear, E. P. (2004), Firm-Specific Human Capital: A Skill-Weights Approach. IZA discussion paper No. 819, Bonn.

Lindley, R. M. (1975), The Demand for Apprentice Recruits by the Engineering Industry: 1951-1971, Scottish Journal of Political Economy 22: 1-24.

Mohrenweiser, J. and U. Backes-Gellner (2008): Apprenticeship Training - what for? Investment in Human Capital or Substitution of Cheap Labour?, mimeo University of Zurich.

Neubäumer, R. and L. Bellmann (1999), Ausbildungsintensität und Ausbildungsbeteiligung von Betrieben: Theoretische Erklärungen und empirische Ergebnisse auf der Basis des IAB Betriebspanels 1997, in: Beer, D.

B. Frick, and W. Sesselmeier (eds.), Die wirtschaftlichen Folgen von Aus- und Weiterbildung, Munich: Hampp: 9-41.

Roodman, D. (2006), How to Do xtabond2: An Introduction to "Difference" and “System” GMM in Stata, Center for Global Development Working Paper 103, Washington D.C..

Ryan, P. (2001), The School-to-Work Transition: A Cross-National Perspective, Journal of Economic Literature 39: 34-92.

Ryan, P., H. Gospel and P. Lewis (2007), Large Employers and Apprenticeship Training in Britain, British Journal of Industrial Relations 45: 127-153.

Soskice, D. (1994), Reconciling Markets and Institutions: The German Apprenticeship System. In L. M. Lynch (Ed.), Training and the Private Sector: International Comparisons , Chicago: University of Chicago Press: 26-60. 
Steedman, H. (2001), Benchmarking Apprenticeship: UK and Continental Europe Compared, CEP Discussion Paper 513, London.

Windmeijer, F. (2005), A Finite Sample Correction for the Variance of Linear Efficient Two-Step GMM Estimators, Journal of Econometrics 126: 25-51.

Wolter, S., S. Mühlemann, and J. Schweri (2006), Why Some Firms Train Apprentices and Many Others Do Not, German Economic Review 7: 249- 264.

Zwick, T. (2004), Employee participation and productivity, Labour Economics 11: 715-740.

Zwick, T. (2007), Apprenticeship training in Germany - investment or productivity driven? Zeitschrift für Arbeitsmarktforschung 40 (2/3): 193-204. 


\section{Appendix}

Table A1: Descriptive Statistics (means at establishment level)

\begin{tabular}{l|cccc}
\hline & mean & sd & minimum & maximum \\
\hline Log(Value Added per Capita) & 10.7928 & 0.8851 & 5.9221 & 16.0026 \\
Log(Gross Profits per Capita)* & 14.7562 & 1.6614 & 6.5207 & 21.1845 \\
\hline Apprentices Occupations: & & & & \\
Commercial and Trade & 0.0110 & 0.0246 & 0.0000 & 0.2698 \\
Manufacturing & 0.0146 & 0.0315 & 0.0000 & 0.4126 \\
Crafts and Construction & 0.0110 & 0.0341 & 0.0000 & 0.4506 \\
Other & 0.0080 & 0.0235 & 0.0000 & 0.3341 \\
\hline Job Characteristics: & & & & \\
Share of Apprentices & 0.0445 & 0.0517 & 0.0000 & 0.4773 \\
Share of Unskilled/Semi-skilled Workers & 0.1776 & 0.2370 & 0.0000 & 1.0000 \\
Share of Skilled Workers & 0.7116 & 0.2551 & 0.0000 & 1.0000 \\
Share of Part Time Workers** & 0.0637 & 0.1422 & 0.0000 & 1.0000 \\
Share of Others & 0.0025 & 0.0119 & 0.0000 & 0.4346 \\
\hline Schooling Level: & & & & \\
Share without a Completed Apprenticeship & 0.1081 & 0.1232 & 0.0000 & 0.9429 \\
Share with a Completed Apprenticeship and & 0.7099 & 0.1883 & 0.0000 & 1.0000 \\
without a Secondary School Degree & & & & \\
Share without a Completed Apprenticeship & 0.0412 & 0.0489 & 0.0000 & 1.0000 \\
and with an Secondary School Degree & & & & \\
Share with a Completed Apprenticeship and & 0.0346 & 0.0446 & 0.0000 & 0.5946 \\
with a Secondary School Degree & & & & \\
Share with a Polytechnic Degree & 0.0488 & 0.0662 & 0.0000 & 0.8279 \\
Share with a University Degree & 0.0574 & 0.0960 & 0.0000 & 0.8844 \\
\hline Share of Foreigners & 0.0369 & 0.0793 & 0.0000 & 0.8375 \\
\hline Establishment Characteristics: & & & & \\
Log(Investment per Capita) & 7.0486 & 3.1714 & 0.0000 & 13.9270 \\
Company founded during last 5 Years & 0.0644 & 0.2455 & 0.0000 & 1.0000 \\
Dummy: Exporting Company & 0.3913 & 0.4881 & 0.0000 & 1.0000 \\
Dummy: Works Council & 0.5747 & 0.4944 & 0.0000 & 1.0000 \\
Dummy: Collective Bargaining Contract & 0.6503 & 0.4769 & 0.0000 & 1.0000 \\
Dummy: Located in East Germany & 0.6131 & 0.4871 & 0.0000 & 1.0000 \\
\hline & & & & \\
\hline
\end{tabular}


Table Al continued:

Firm Size Categories:

$20-100$

$101-500$

$>500$

Number of Observations

Number of Establishments

\begin{tabular}{l|cccc} 
& & & & \\
& 0.5881 & 0.7676 & 0.0000 & 1.0000 \\
& 0.3245 & 0.4682 & 0.0000 & 1.0000 \\
& 0.0874 & 0.2824 & 0.0000 & 1.0000 \\
\hline ns & 5916 & & & \\
\hline
\end{tabular}

* Profit per capita and investment per capita are added with a constant - the largest negative number found in the variables - to make sure that all values are positive and hence can be logarithmised.

** Full time workers can be divided in different job characteristics but not part time workers.

Source: LIAB Wave 1997 - 2002, sample used for System GMM regressions, see Tables $A 4$ and $A 5$. 
Table A2: OLS Estimations

\begin{tabular}{l|c|c|c|c}
\hline \hline & \multicolumn{2}{|c|}{ Productivity } & \multicolumn{2}{c}{ Gross Profits } \\
\hline & Coef. & t-Value & Coef. & t-Value \\
\hline Share of Apprentice Occupation Group & & & & \\
(Ref.: Unskilled Workers): & 2.3047 & 5.97 & 1.8628 & 7.61 \\
Commercial and Trade & -0.9650 & -3.10 & -0.6416 & -3.25 \\
Manufacturing & -1.3709 & -4.70 & -0.6695 & -3.62 \\
Crafts and Construction & & & & \\
Further Job Characteristics (Ref: & & & & \\
Unskilled Workers): & 0.0613 & 1.24 & 0.0110 & 0.35 \\
Share of Skilled Workers & -0.1635 & -2.15 & 0.0719 & 1.49 \\
Share of Part Time Workers & & & & \\
\hline Schooling Level (Ref:: without Completed & & & & \\
Apprenticeship and with Secondary School & & & & \\
Degree): & -0.3768 & -2.97 & -0.1815 & -2.26 \\
Share without a Completed Apprenticeship & -0.2542 & -2.89 & -0.1031 & -1.85 \\
Share with a Completed Apprenticeship & & & & \\
and without a Secondary School Degree & 1.5043 & 6.97 & 0.9397 & 6.87 \\
Share with a Completed Apprenticeship & & & & \\
and with an Secondary School Degree & 0.3906 & 2.27 & 0.2322 & 2.13 \\
Share with a Polytechnic Degree & 0.7134 & 5.04 & 0.3197 & 3.56 \\
Share with a University Degree & -0.2030 & -1.37 & -0.1914 & -2.03 \\
\hline Share of Foreigners & & & & \\
\hline Establishment Characteristics: & 0.0804 & 18.35 & 0.0484 & 17.43 \\
Log(Investment per Capita) & 0.0415 & 1.28 & 0.0464 & 2.26 \\
Company founded during last 5 Years & 0.1464 & 6.10 & 0.0752 & 4.94 \\
Dummy: Exporting Company & 0.2079 & 9.29 & 0.0750 & 5.29 \\
Dummy: Works Council & 0.0458 & 2.13 & 0.0218 & 1.60 \\
Dummy: Collective Bargaining Contract & -0.4437 & -18.89 & -0.1843 & -12.38 \\
Dummy: Located in East Germany & 0.2397 & & 0.1773 & \\
\hline R & 67.46 & & 46.11 & \\
F (38, 8130) & 8169 & & 8169 & \\
Number of Establishments (Observations) & & & \\
\hline \hline Notes: Regressions also inchuce 2 firm size & & & & \\
\hline
\end{tabular}

Notes: Regressions also include 2 firm size dummies, 11 industry, 1 dummy for employees with unknown occupational qualification, 1 dummy for apprentices with other occupations, and 5 year dummies. Productivity: log(value added per capita), Gross Profits: $\log$ (value added minus total wage bill per capita).

Source: LIAB 1997-2002 
Table A3: Fixed Effect Estimation

\begin{tabular}{|c|c|c|c|c|}
\hline & \multicolumn{2}{|c|}{ Productivity } & \multicolumn{2}{|c|}{ Gross Profits } \\
\hline & Coef. & t-Value & Coef. & t-Value \\
\hline $\begin{array}{l}\text { Share of Apprentice Occupation Group } \\
\text { (Ref.: Unskilled Workers): }\end{array}$ & & & & \\
\hline Commercial and Trade & -0.0913 & -0.15 & -0.3443 & -0.91 \\
\hline Manufacturing & -0.4404 & -0.81 & -0.2180 & -0.65 \\
\hline Crafts and Construction & 0.1393 & 0.24 & 0.2423 & 0.68 \\
\hline $\begin{array}{l}\text { Further Job Characteristics (Ref: } \\
\text { Unskilled Workers): }\end{array}$ & & & & \\
\hline Share of Skilled Workers & 0.1728 & 1.00 & 0.0882 & 0.83 \\
\hline Share of Part Time Workers & 1.1293 & 4.56 & 0.6940 & 4.55 \\
\hline $\begin{array}{l}\text { Schooling Level (Ref.: without Completed } \\
\text { Apprenticeship and with Secondary School } \\
\text { Degree): }\end{array}$ & & & & \\
\hline Share without a Completed Apprenticeship & 0.1043 & 0.26 & -0.1200 & -0.49 \\
\hline $\begin{array}{l}\text { Share with a Completed Apprenticeship } \\
\text { and without a Secondary School Degree }\end{array}$ & -0.1600 & -0.47 & -0.2716 & -1.30 \\
\hline $\begin{array}{l}\text { Share with a Completed Apprenticeship } \\
\text { and with an Secondary School Degree }\end{array}$ & 0.3035 & 0.57 & -0.0288 & -0.09 \\
\hline Share with a Polytechnic Degree & -0.0874 & -0.17 & -0.6528 & -2.10 \\
\hline Share with a University Degree & -0.1808 & -0.38 & -0.2748 & -0.94 \\
\hline Share of Foreigners & -1.5490 & -4.08 & -1.1808 & -5.05 \\
\hline Establishment Characteristics: & & & & \\
\hline Log(Investment per Capita) & 0.0373 & 1.87 & 0.0069 & 0.56 \\
\hline Company founded during last 5 Years & -0.0153 & -0.41 & 0.0285 & 1.24 \\
\hline Dummy: Exporting Company & 0.0192 & 0.65 & 0.0063 & 0.34 \\
\hline $\mathrm{R}^{2}$ & 0.0174 & & 0.0195 & \\
\hline$F(23,6019)$ & 4.63 & & 5.21 & \\
\hline Number of Establishments (Groups) & 2146 & & 2146 & \\
\hline
\end{tabular}

Notes: Regressions include 2 firm size dummies, 1 dummy for employees with unknown occupational qualification, 1 dummy for apprentices with other occupations, and 5 year dummies. Productivity: log(value added per capita), Gross Profits: log(value added minus total wage bill per capita).

Source: LIAB 1997-2002. 
Table A4: System GMM Estimation

\begin{tabular}{|c|c|c|c|c|}
\hline & \multicolumn{2}{|c|}{ Productivity } & \multicolumn{2}{|c|}{ Gross Profits } \\
\hline & Coef. & t-Value & Coef. & t-Value \\
\hline L1 (y) & 0.4733 & 10.37 & 0.4887 & 9.76 \\
\hline $\begin{array}{l}\text { Share of Apprentice Occupation Group } \\
\text { (Ref:: Unskilled Workers): }\end{array}$ & & & & \\
\hline Commercial and Trade & 3.8442 & 1.94 & 2.5895 & 2.02 \\
\hline L1 & -1.9406 & -1.30 & -0.8102 & -1.12 \\
\hline Manufacturing & -0.1603 & -0.07 & -0.5222 & -0.36 \\
\hline L1 & -0.1118 & -0.05 & 0.5898 & 0.44 \\
\hline Crafts and Construction & -0.4390 & -0.23 & 0.3236 & 0.29 \\
\hline L1 & -0.9130 & -0.51 & -0.9206 & -0.88 \\
\hline $\begin{array}{l}\text { Further Job Characteristics (Ref: Unskilled } \\
\text { Workers): }\end{array}$ & & & & \\
\hline Share of Skilled Workers & 0.6837 & 1.19 & 0.1770 & 0.49 \\
\hline L1 & -0.5879 & -1.11 & -0.1799 & -0.53 \\
\hline Share of Part Time Workers & 1.4794 & 1.53 & 0.5766 & 0.96 \\
\hline L1 & -0.9690 & -0.99 & -0.2286 & -0.38 \\
\hline $\begin{array}{l}\text { Schooling Level (Ref.: without Completed } \\
\text { Apprenticeship and with Secondary School } \\
\text { Degree): }\end{array}$ & & & & \\
\hline Share without a Completed Apprenticeship & 0.3621 & 0.64 & 0.1897 & 0.54 \\
\hline $\begin{array}{l}\text { Share with a Completed Apprenticeship and } \\
\text { without a Secondary School Degree }\end{array}$ & -0.0357 & -0.10 & -0.0186 & -0.09 \\
\hline $\begin{array}{l}\text { Share with a Completed Apprenticeship and } \\
\text { with an Secondary School Degree }\end{array}$ & 1.7184 & 1.89 & 1.2333 & 1.99 \\
\hline Share with a Polytechnic Degree & 1.5658 & 1.95 & 1.0828 & 1.87 \\
\hline Share with a University Degree & -0.0012 & 0.00 & -0.4434 & -1.02 \\
\hline Share of Foreigners & -1.0700 & -1.35 & -0.5971 & -1.04 \\
\hline Establishment Characteristics: & & & & \\
\hline Log(Investment per Capita) & 0.0056 & 0.21 & 0.0037 & 0.23 \\
\hline L1 & 0.0087 & 0.32 & -0.0033 & -0.20 \\
\hline Company founded during last 5 Years & 0.0379 & 1.04 & 0.0225 & 0.98 \\
\hline Dummy: Exporting Company & 0.0809 & 2.40 & 0.0502 & 2.35 \\
\hline
\end{tabular}


Table A4 continued:

Dummy: Works Council

Dummy: Collective Bargaining Contract

Dummy: Located in East Germany

Number of Establishments (Groups)

Number of Instruments

Wald chi2(46)

Arellano-Bond Test for AR(1) in First

Differences (p-Value)

Arellano-Bond Test for AR(2) in First

Differences (p-Value)

Hansen Test of Over-Identification

Restrictions (p-Value)

Notes: Regressions include 2 firm size dummies, 1 dummy for employees with unknown occupational qualification, 1 dummy for apprentices with other occupations, 11 industry and 5 year dummies. Productivity: log(value added per capita), Gross Profits: log(value added minus total wage bill per capita). Source: LIAB 1997 - 2002

Table A5: Minimum Distance Estimator after System GMM

\begin{tabular}{l|c|c|c|c}
\hline \hline & \multicolumn{2}{|c|}{ Productivity } & \multicolumn{2}{c}{ Gross Profits } \\
\hline & Coef. & t-Value & Coef. & t-Value \\
\hline L1 (y) & 0.4417 & 11.27 & 0.4661 & 10.42 \\
\hline Share of Apprentice Occupation Group & & & & \\
(Ref.: Unskilled Workers): & & & & \\
Commercial and Trade & 2.5468 & 3.58 & 0.9683 & 2.78 \\
Manufacturing & -0.0277 & -0.04 & -1.2437 & -2.65 \\
Crafts and Construction & 1.3915 & 2.22 & 1.4731 & 3.80 \\
Further Job Characteristics (Ref: & & & & \\
Unskilled Workers): & & & & \\
Share of Skilled Workers & 0.9723 & 5.09 & 0.2696 & 2.31 \\
Share of Part Time Workers & 1.3336 & 4.03 & 0.1687 & 0.85 \\
\hline Log(Investment per Capita) & -0.0105 & -0.84 & 0.0065 & 0.82 \\
\hline \hline
\end{tabular}

Note: Only variable displayed which includes contemporary and lagged variables. 
Table A6: Lagged OLS

\begin{tabular}{|c|c|c|c|c|}
\hline & \multicolumn{2}{|c|}{ Productivity } & \multicolumn{2}{|c|}{ Gross Profits } \\
\hline & Coef. & t-Value & Coef. & t-Value \\
\hline L1 (y) & 0.7084 & 80.39 & 0.7230 & 84.08 \\
\hline $\begin{array}{l}\text { Share of Apprentice Occupation Group } \\
\text { (Ref.: Unskilled Workers): }\end{array}$ & & & & \\
\hline Commercial and Trade & 2.3221 & 3.46 & 1.2228 & 2.92 \\
\hline L1 & -1.0420 & -1.59 & -0.2485 & -0.61 \\
\hline Manufacturing & -0.9361 & -1.72 & -0.7176 & -2.12 \\
\hline L1 & 0.5229 & 0.93 & 0.4876 & 1.39 \\
\hline Crafts and Construction & 0.4408 & 0.77 & 0.3296 & 0.93 \\
\hline L1 & -0.9176 & -1.64 & -0.5368 & -1.54 \\
\hline $\begin{array}{l}\text { Further Job Characteristics (Ref: } \\
\text { Unskilled Workers): }\end{array}$ & & & & \\
\hline Share of Skilled Workers & 0.3414 & 1.92 & 0.1625 & 1.47 \\
\hline L1 & -0.3044 & -1.74 & -0.1489 & -1.36 \\
\hline Share of Part Time Workers & 0.8089 & 2.98 & 0.5445 & 3.22 \\
\hline L1 & -0.9158 & -3.35 & -0.5349 & -3.14 \\
\hline $\begin{array}{l}\text { Schooling Level (Ref.: without Completed } \\
\text { Apprenticeship and with Secondary School } \\
\text { Degree): }\end{array}$ & & & & \\
\hline Share without a Completed Apprenticeship & -0.0957 & -0.95 & -0.0097 & -0.15 \\
\hline $\begin{array}{l}\text { Share with a Completed Apprenticeship } \\
\text { and without a Secondary School Degree }\end{array}$ & -0.0133 & -0.19 & 0.0429 & 0.98 \\
\hline $\begin{array}{l}\text { Share without a Completed Apprentice- } \\
\text { ship and with an Secondary Degree }\end{array}$ & 0.5951 & 3.34 & 0.4109 & 3.71 \\
\hline Share with a Polytechnic Degree & -0.0011 & -0.01 & 0.0581 & 0.68 \\
\hline Share with a University Degree & 0.2283 & 2.03 & 0.1463 & 2.09 \\
\hline Share of Foreigners & 0.0360 & 0.31 & 0.0198 & 0.27 \\
\hline
\end{tabular}


Table A6 continued:

Establishment Characteristics:

Log(Investment per Capita)

L1

Company founded during last 5 Years

Dummy: Exporting Company

Dummy: Works Council

Dummy: Collective Bargaining Contract

Dummy: Located in East Germany

$\mathrm{R}^{2}$

$\mathrm{F}(46$, 5869)

Number of Establishments (Observations)

\begin{tabular}{|c|c|c|c} 
& & & \\
0.0313 & 1.51 & 0.0092 & 0.72 \\
-0.0029 & -0.14 & 0.0076 & 0.59 \\
0.0355 & 1.25 & 0.0198 & 1.12 \\
0.0667 & 3.52 & 0.0387 & 3.28 \\
0.0573 & 3.28 & 0.0244 & 2.26 \\
0.0316 & 1.88 & 0.0148 & 1.42 \\
-0.1187 & -6.28 & -0.0448 & -3.86 \\
\hline 0.6471 & & 0.6354 & \\
233.93 & & 222.35 & \\
5916 & & 5916 & \\
\hline
\end{tabular}

Notes: Regressions also include 2 firm size dummies, 11 industry, 1 dummy for employees with unknown occupational qualification, 1 dummy for apprentices with other occupations, and 5 year dummies. Productivity: log(value added per capita), Gross Profits: $\log$ (value added minus total wage bill per capita).

Source: LIAB 1997-2002. 
Table A7: Lagged Fixed Effect Estimation

\begin{tabular}{l|c|c|c|c}
\hline \hline & \multicolumn{2}{|c|}{ Productivity } & \multicolumn{2}{c}{ Gross Profits } \\
\hline L1 (y) & Coef. & t-Value & Coef. & t-Value \\
\hline Share of Apprentice Occupation Group & 0.0411 & 2.79 & 0.0481 & 3.17 \\
(Ref.: Unskilled Workers): & & & & \\
Commercial and Trade & 0.7019 & 0.81 & -0.0775 & -0.14 \\
L1 & -1.9786 & -2.71 & -0.8732 & -1.90 \\
Manufacturing & -1.2974 & -1.99 & -0.8266 & -2.01 \\
L1 & 1.6877 & 2.63 & 1.2324 & 3.04 \\
Crafts and Construction & 1.4828 & 1.98 & 0.6088 & 1.29 \\
L1 & -0.6831 & -1.02 & -0.0427 & -0.10 \\
Further Job Characteristics (Ref: & & & & \\
Unskilled Workers): & & & & \\
Share of Skilled Workers & 0.0433 & 0.19 & 0.0613 & 0.42 \\
L1 & -0.0792 & -0.36 & -0.0506 & -0.36 \\
Share of Part Time Workers & 1.5477 & 4.33 & 0.8436 & 3.74 \\
L1 & -0.3273 & -0.98 & -0.1153 & -0.55 \\
\hline Schooling Level (Ref.: without Completed & & & & \\
Apprenticeship and with Secondary School & & & & \\
Degree): & & & & \\
Share without a Completed Apprenticeship & -0.4590 & -0.93 & -0.4228 & -1.35 \\
Share with a Completed Apprenticeship & -0.5749 & -1.33 & -0.4304 & -1.58 \\
and without a Secondary School Degree & -0.0044 & -0.01 & -0.1121 & -0.26 \\
Share without a Completed Apprentice- & -0.1773 & -0.28 & -0.7332 & -1.83 \\
ship and with an Secondary Degree & -0.0052 & -0.01 & -0.3627 & -0.95 \\
Share with a Polytechnic Degree & -1.5410 & -3.26 & -1.2274 & -4.11 \\
Share with a University Degree & & & \\
\hline Share of Foreigners & & & \\
\hline & & & & \\
\hline
\end{tabular}


Table A7 continued:

Establishment Characteristics:

Log(Investment per Capita)

L1

Company founded during last 5 Years

Dummy: Exporting Company

$\mathrm{R}^{2}$

$\mathrm{F}(31,4006)$

Number of Establishments (Groups)

\begin{tabular}{l|c|c|c|c} 
& & & & \\
& 0.0009 & 0.04 & -0.0028 & -0.17 \\
0.0212 & 0.87 & 0.0028 & 0.18 \\
& -0.0019 & -0.04 & 0.0254 & 0.83 \\
& -0.04 & -1.03 & -0.03 & -1.19 \\
\hline & 0.0262 & & 0.0266 & \\
& 3.48 & & 3.53 & \\
\hline
\end{tabular}

Notes: Regressions include 2 firm size dummies, 5 year dummies, 1 dummy for employees with unknown occupational qualification. Productivity: log(value added per capita), Gross Profits: $\log$ (value added minus total wage bill per capita).

Source: LIAB 1997-2002.

Table A8: List of occupational categories

\begin{tabular}{l|c}
\hline \hline & Number of occupation in IABS \\
\hline Commercial and Trade & $681-706,751-773,781-784,856,922$ \\
Manufacturing & $141-162,191-291,311-323,541-543,547,631-634,744,857$ \\
Crafts and Construction & $53,121-135,163-177,302-306,391-422,441-514,544-$ \\
& $546,741-744,804,901-921,923-937$ \\
\hline \hline
\end{tabular}

Note: the plain text of the selected occupations can be found in Alda (2005). 